\title{
Glucose modulation of aldose reductase mRNA expression and its activity in cultured calf pulmonary artery endothelial cells
}

\author{
M. Ohtaka, M. Tawata, Y.Hosaka and T. Onaya \\ The Third Department of Internal Medicine, University of Yamanashi Medical School, Tamaho, Yamanashi, Japan
}

\begin{abstract}
Summary. We examined the effect of glucose on aldose reductase mRNA expression and its activity in calf pulmonary artery endothelial cells. After the cells were exposed to $18 \mathrm{mmol} / \mathrm{l}$ glucose, aldose reductase mRNA expression began to increase at $6 \mathrm{~h}$, reached a maximum (about 2.4-fold increase) at $12 \mathrm{~h}$, and thereafter gradually decreased. Aldose reductase activity was found to strongly correlate with aldose reductase mRNA expression after cells were exposed to $18 \mathrm{mmol} / \mathrm{l}$ glucose. In contrast, aldose reductase mRNA expression was significantly decreased following exposure to $55 \mathrm{mmol} / 1$ glucose. Aldose reductase activity was also decreased at $24 \mathrm{~h}$ after $55 \mathrm{mmol} / \mathrm{l}$ glucose. The increase in al-
\end{abstract}

dose reductase mRNA level caused by glucose was inhibited by $1 \mu \mathrm{g} / \mathrm{ml}$ of actinomycin $\mathrm{D}$. These phenomena appear to be glucose-specific since neither 3-O-methylglucose nor fructose affected the levels of aldose reductase mRNA. We clearly demonstrate that aldose reductase mRNA level and its activity are modulated by glucose in calf pulmonary artery endothelial cells. Our data suggest that activation of aldose reductase in endothelial cells may contribute to the development of diabetic macroangiopathy.

Key words: Diabetes mellitus, angiopathy, endothelial cells, glucose, aldose reductase.
Hyperglycaemia is a generally accepted risk factor for development of diabetic macro- and microangiopathies. According to the 'response to injury' thesis [1,2], denuding or non-denuding injury of the endothelium may be an initial event in the pathogenesis of atherosclerosis. Unlike muscle and adipose tissues, the tissues most affected by diabetes (i.e., the lens, nerve, retina, kidney, blood vessels, and islet cells) are freely permeable to glucose and do not require insulin for glucose penetration. They are exposed to the ambient blood glucose levels, and thus accumulate glucose. In the affected cells a portion of the accumulated glucose is converted to sorbitol by the enzyme aldose reductase (AR) [3]. Because sorbitol is not freely permeable and is slowly metabolized, it accumulates within the cell [4]. In vivo experiments in rats have shown that diabetes mellitus causes an increase in vascular permeability, as measured by albumin permeation [5]. The increase in vascular permeability is accompanied by an increase in sorbitol levels [5]. These changes are corrected by treating the diabetic animals with the aldose reductase inhibitor, sorbinil [5]. Glucose uptake by the endothelial cells of large vessels also occurs independently of insulin, and the cells have been shown to accumulate sorbitol when exposed to high ambient glucose levels. Recent studies have reported on AR mRNA expression in kidney [6] and lens $[7,8]$ under hypertonic conditions. In this study, we quantitated $A R$ activity and mRNA in calf pulmonary artery endothelial cells (CPAE) under normal and high ambient glucose levels in the culture medium.

\section{Materials and methods}

\section{Cell culture}

CPAE cells were obtained from Dainippon Pharmaceutical Co. (Osaka, Japan) and seeded in $100 \mathrm{~mm}$ dishes (Nunc, Copenhagen, Denmark). The growth medium was minimum essential medium (MEM) (Gibco Laboratories, Grand Island, NY, USA) containing $20 \%$ fetal calf serum (FCS). Cultures were incubated in $10 \mathrm{ml}$ of medium at $37^{\circ} \mathrm{C}$ in a humidified $5 \% \mathrm{CO}_{2}-95 \%$ air atmosphere. When the cells reached confluency, the concentration of FCS was decreased to $2 \%$ for $24 \mathrm{~h}$, then decreased to $0.1 \%$. After a further $48 \mathrm{~h}$ incubation, the cells were exposed to various concentrations of glucose. The cells were then harvested at the times indicated in the experimental conditions. The culture medium was replaced every $12 \mathrm{~h}$ to keep the glucose concentrations relatively constant.

\section{Quantitative analysis of AR $m R N A$}

We slightly modified the method of Chelly et al. [9] and Wang et al. $[10]$ to measure mRNA levels. Total RNA was obtained using the standard method of $6 \mathrm{~mol} / \mathrm{l}$ guanidine thiocyanate $/ \mathrm{CsCl}$ centrifuga- 

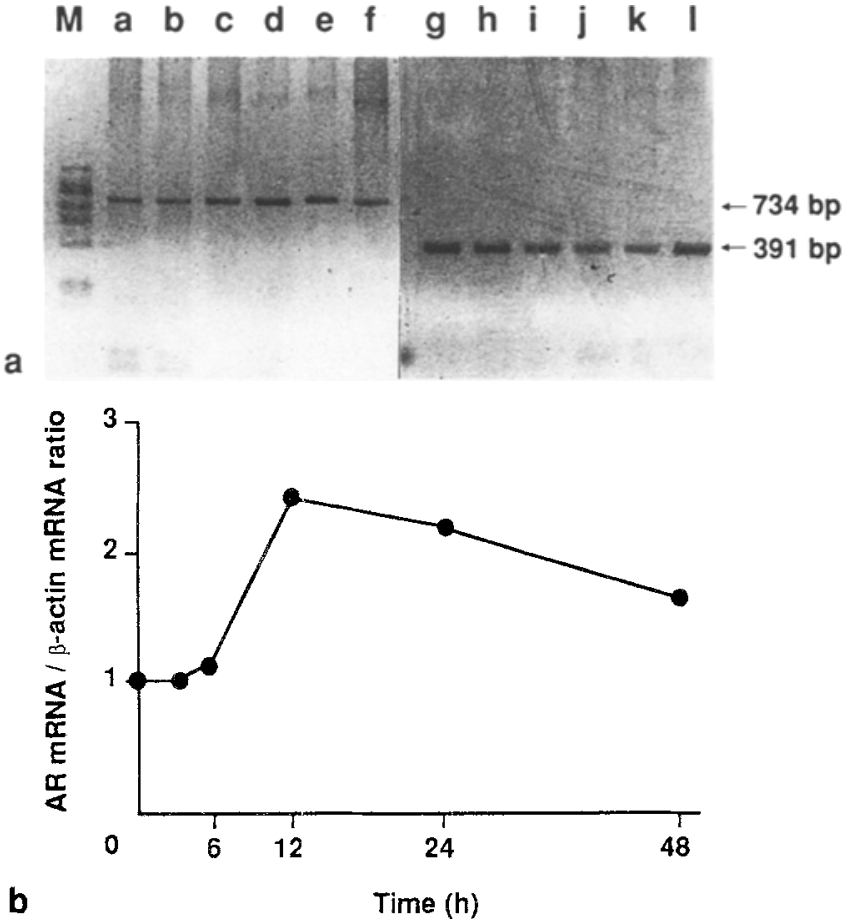

Fig. 1a,b. Time course of aldose reductase (AR) mRNA expression after addition of $18 \mathrm{mmol} / \mathrm{l}$ glucose. a Ethidium bromide staining of polymerase chain reaction (PCR) products separated in $2 \%$ agarose. Lanes: $\mathrm{M}$, molecular weight markers; a-f, AR PCR products; $\mathrm{g}-\mathrm{l}, \beta$-actin PCR products; lanes a and g, $0 \mathrm{~h}$; lanes $\mathrm{b}$ and h, $3 \mathrm{~h}$; lanes $\mathrm{c}$ and i, $6 \mathrm{~h}$; lanes d and j, $12 \mathrm{~h}$; lanes e and k, $24 \mathrm{~h}$; lanes f and 1, $48 \mathrm{~h}$. bp, base pairs. b The ordinate indicates AR mRNA/ $\beta$-actin mRNA ratio in arbitrary units and abscissa indicates time in $h$. Each point is the mean of the duplicates from a representative experiment

tion [11]. RNA was reverse-transcribed into cDNA by the following procedures as previously described [12]. Total cellular RNA $(4 \mu \mathrm{g})$ was heated at $70^{\circ} \mathrm{C}$ for $10 \mathrm{~min}$, cooled slowly to $42^{\circ} \mathrm{C}$, and then reverse-transcribed at $42^{\circ} \mathrm{C}$ for 90 minin a $25 \mu 1$ reaction mixture containing $50 \mathrm{mmol} / \mathrm{l}$ Tris- $\mathrm{HCl}(\mathrm{pH} 8.3), 100 \mathrm{mmol} / \mathrm{l} \mathrm{KCl}, 10 \mathrm{mmol} / \mathrm{l}$ $\mathrm{MgCl}_{2}, 10 \mathrm{mmol} / \mathrm{l}$ dithiothreitol, $0.25 \mathrm{mmol} / 1$ deoxynucleoside triphosphates (dNTP), $0.4 \mu \mathrm{g}$ oligo-dT, 400 units of RNasin (Takara Shuzo Co., Kyoto, Japan), and 11 units of Rous associated virus 2 (RAV-2) reverse transcriptase (Takara). A $20 \mu \mathrm{l}$ aliquot of a 1:10 diluted cDNA mixture was used as the template for amplification. Polymerase chain reaction (PCR) was performed at a final concentration of $1 \times$ PCR buffer $\left(50 \mathrm{mmol} / 1\right.$ Tris- $\mathrm{HCl} \mathrm{pH} 8.3,2 \mathrm{mmol} / 1 \mathrm{MgCl}_{2}$, $30 \mathrm{mmol} / 1 \mathrm{KCl}, 10 \mathrm{mmol} / \mathrm{l}$ dithiothreitol), $0.25 \mathrm{mmol} / 1 \mathrm{dNTP}, 1 \mu \mathrm{g}$ each of upstream and downstream primers, $1 \times 10^{6} \mathrm{cpm}$ of ${ }^{32} \mathrm{P}$-endlabelled upstream primer and 2.5 units of thermus aquatics DNA polymerase (taq polymerase) (Perkin-Elmer/Cetus, Norwalk, Conn., USA) in a total volume of $50 \mu \mathrm{I}$. The mixture was overlaid with mineral oil and then amplified with COY Temp Cycler (Toyobo, Osaka, Japan). The amplification profile involved denaturation at $93^{\circ} \mathrm{C}$ for $60 \mathrm{~s}$, primer annealing at $60^{\circ} \mathrm{C}$ for $90 \mathrm{~s}$, and extension at $72^{\circ} \mathrm{C}$ for $90 \mathrm{~s}$. At the first cycle, however, DNA was denaturated for $5 \mathrm{~min}$. To ensure exponential amplification, AR mRNA amplification was carried out for 25 cycles, and $\beta$-actin mRNA amplification for 22 cycles. To remove the mineral oil, the reaction mixtures were extracted once with chloroform and were then prepared for quantitation.

A $12.5 \mu 1$ aliquot of each PCR reaction mixture was electrophoresed in $2 \%$ agarose gels in Tris-acetate/EDTA buffer containing ethidium bromide. The appropriate bands were then cut from the gel and radioactivity was determined by scintillation counting. The results were expressed as the ratio between AR mRNA and $\beta$ actin mRNA. The intra-assay and inter-assay coefficients of variations were less than $5 \%$
Oligonucleotides used for amplification

AR primers were chosen from the bovine lens AR CDNA sequence [13]. $\beta$-Actin primers, to be used as an internal standard, were chosen from the rat $\beta$-actin cDNA sequence [14]. They were synthesized using a DNA synthesizer (Applied Biosystems, Tokyo, Japan). The $5^{\prime}$ end of the upstream primers were labelled with $\left[\mathcal{\gamma}^{32} \mathrm{P}\right] \mathrm{ATP}$ using $\mathrm{T}_{4}$ polynucleotide kinase. Unincorporated nucleotides were removed using ultrafree-C3 (Japan Millipore Laboratories, Tokyo, Japan)

The AR upstream primer (5' TACCAGAATGAGAACGAGGT $3^{\prime}$ ) is identical to nucleotides 87 to 106 of the cDNA. The AR downstream primer (5' TTGTAGCTCAGCAAGGTGTT $3^{\prime}$ ) is complementary to nucleotides 801 to 820 .

The $\beta$-actin upstream primer (5' TGT'TTGAGACCTTCA$A C A C C 3^{\prime}$ ) is identical to nucleotides 368 to 387 of the cDNA. The $\beta$-actin downstream primer ( 5 ' CGCTCATTGCCGATAGTGAT $3^{\prime}$ ) is complementary to nucleotides 739 to 758 .

\section{Measurement of AR activity}

Harvested CPAE cells were ultrasonically disrupted in $135 \mathrm{mmol} / \mathrm{l}$ $\mathrm{Na}, \mathrm{K}$-phosphate buffer $\mathrm{pH} 7.0$, followed by centrifugation at $15000 \mathrm{rev} / \mathrm{min}$ for $15 \mathrm{~min}$. The supernatants were assumed to be the crude aldose reductase enzyme fraction. AR activity was measured according to the method reported by Dufrane et al. [15]. Incubation was carried out in $1 \mathrm{ml}$ of incubation medium $(135 \mathrm{mmol} / \mathrm{Na}, \mathrm{K}$ phosphate buffer $\mathrm{pH} 7.0,0.1 \mathrm{~mol} / 1 \mathrm{LiSO}_{4}, 0.1 \mathrm{mmol} / 1 \mathrm{Dc}$-glyceraldehyde, $0.03 \mathrm{mmol} / \mathrm{NADPH}$ ) at $30^{\circ} \mathrm{C}$ for $30 \mathrm{~min}$, and was then terminated by the addition of $0.3 \mathrm{ml}$ of $0.5 \mathrm{~mol} / \mathrm{h} \mathrm{HCl}$. One $\mathrm{ml}$ of $6 \mathrm{~mol} / \mathrm{l}$ $\mathrm{NaOH}$ containing $10 \mathrm{mmol} / \mathrm{l}$ imidazole was then added, fluorescent NADP was measured by fluorescence spectrophotometry at an excitation wavelength of $360 \mathrm{~nm}$ and an emission wavelength of $460 \mathrm{~nm}$. An excitation and an emission band pass was set at $10 \mathrm{~nm}$. AR activity was corrected by the cell number.

\section{Statistical analysis}

Data are means \pm SEM. Statistical analysis was carried out with Student's $t$-test.

\section{Results}

In this study we used PCR to examine whether or not AR mRNA is expressed in CPAE cells. The amplified AR cDNA and $\beta$-actin cDNA were found as a single band after agarose gel electrophoresis and migrated at a predicted size of 734 and 391 base pairs, respectively (Fig. 1a). Direct sequencing of the amplified DNAs using the asymmetric PCR technique [16] demonstrated over 95\% homology to bovine lens cDNA and rat $\beta$-actin cDNA (data not shown).

\section{Time course of $A R$ IRNA expression}

We studied the ability of glucose to influence AR mRNA expression. The time course of AR mRNA expression after exposure of quiescent CPAE cells to $18 \mathrm{mmol} / \mathrm{lglu}-$ cose was determined using PCR quantitative analysis. As shown in Figure 1 ( $a$ and $b$ ), ARmRNA levels began to increase at $6 \mathrm{~h}$ after glucose exposure, reached a maximum at $12 \mathrm{~h}$ (about 2.4-fold increase), and then gradually decreased. Figure $1 \mathrm{~b}$ shows the AR mRNA/ $\beta$-actin mRNA ratio. 


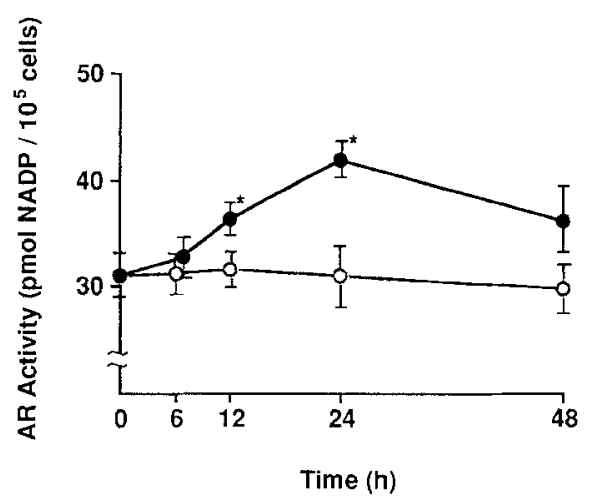

Fig. 2. Time course of aldose reductase (AR) activity after addition of $18 \mathrm{mmol} / \mathrm{l}$ glucose. The ordinate indicates AR activity, and the abscissa indicates time in $\mathrm{h}$. The open and closed circles indicate $5.5 \mathrm{mmol} / \mathrm{l}$ and $18 \mathrm{mmol} / \mathrm{h}$ glucose, respectively. Values are means $\pm S E M$ for three independent experiments. ${ }^{*} p<0.05$ vs control culture

\section{Time course of AR activity}

A time course evaluation of $\mathrm{AR}$ activity was performed following the addition of $18 \mathrm{mmol} / \mathrm{l}$ glucose. AR activity was found to correlate with AR mRNA levels. AR activity reached a maximum (about 1.3-fold) at $24 \mathrm{~h}$, and thereafter gradually decreased (Fig. 2). In contrast, at a glucose concentration of $55 \mathrm{mmol} / \mathrm{l}$, AR activity gradually decreased until $24 \mathrm{~h}$ after glucose exposure, followed by a plateau (about 0.4-fold, data not shown).

\section{Concentration dependency of $A R M R N A$ expression}

Figure 3 a shows the concentration dependency of $A R$ mRNA expression at $12 \mathrm{~h}$ after glucose exposure. The expression of AR mRNA was found to follow a biphasic pattern. The AR mRNA/ $\beta$-actin mRNA ratio increased up to $18 \mathrm{mmol} / \mathrm{l}$ glucose; however, at higher concentrations of glucose, the AR mRNA/ $\beta$-actin mRNA ratio gradually decreased.

\section{Concentration dependency of $A R$ activity}

The concentration dependency of $A R$ activity is shown in Figure $3 \mathrm{~b}$. AR activity was found to have a strong correlation with $\mathrm{AR} m \mathrm{~m} N \mathrm{~A}$ level. After exposure to glucose, $\mathrm{AR}$ activity reached a maximum at $18 \mathrm{mmol} / \mathrm{l}$ glucose, but decreased when the glucose concentration was raised over $30 \mathrm{mmol} / 1$.

\section{The effect of actinomycin D on AR $m R N A$ expression}

We also studied whether the stimulatory effects of glucose on AR mRNA levels occurred via a transcriptional or non-transcriptional mechanism. One microgram per millilitre of actinomycin $\mathrm{D}$ was added $30 \mathrm{~min}$ before the addition of glucose and CPAE cells were exposed to glucose for $12 \mathrm{~h}$. As shown in Figure 4, AR mRNA expression by glucose was completely suppressed.

\section{The effect of other sugars on AR $m R N A$ expression}

By testing other sugars and osmolytes, we also studied whether the induction of AR mRNA expression is specific for glucose. As shown in Figure 5, glucose, fructose or 3O-methylglucose at $18 \mathrm{mmol} / \mathrm{l}$ were each added to the medium. There was an increase in AR mRNA expression only after the addition of $18 \mathrm{mmol} / \mathrm{l}$ glucose.

\section{Discussion}

Diabetic patients have an increased incidence and severity of atherosclerosis. Several theories have been proposed to explain why diabetic patients are at an increased risk for such vascular disorders. In uncontrolled diabetes, excess glucose causes a glycation of various proteins [17], a decrease in the level of oxygen dissociation in erythrocytes, an increase in platelet aggregation [18, 19], an increase in the circulatory level of very low density lipoproteins, and a decrease in high density lipoproteins [20]. In addition, Yamauchi et al. [21] recently reported that elevated glucose levels enhance the secretion of endothelin-1 in cultured bovine aortic endothelial cells.

\section{a}

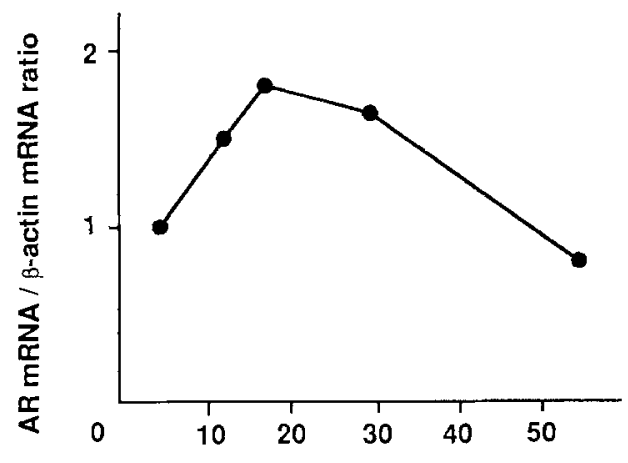

b

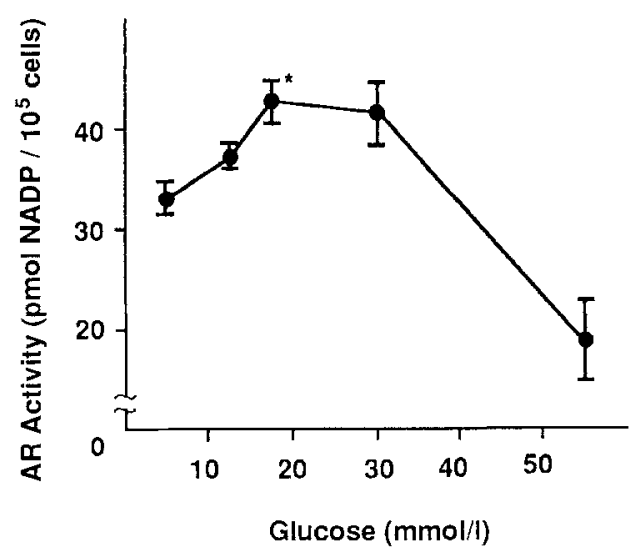

Fig.3. a Concentration dependency of aldose reductase (AR) mRNA at $12 \mathrm{~h}$ after glucose exposure. The ordinate indicates $A R$ mRNA/ $\beta$-actin mRNA ratio in arbitrary units, and abscissa indicates glucose concentration. Each point is the mean of the duplicates from a representative experiment. $\mathbf{b}$ Concentration dependency of AR activity at $24 \mathrm{~h}$ after glucose exposure. The ordinate indicates AR activity, and the abscissa indicates glucose concentration. Values are means \pm SEM for three independent experiments. ${ }^{*} p<0.05$ vs control culture 


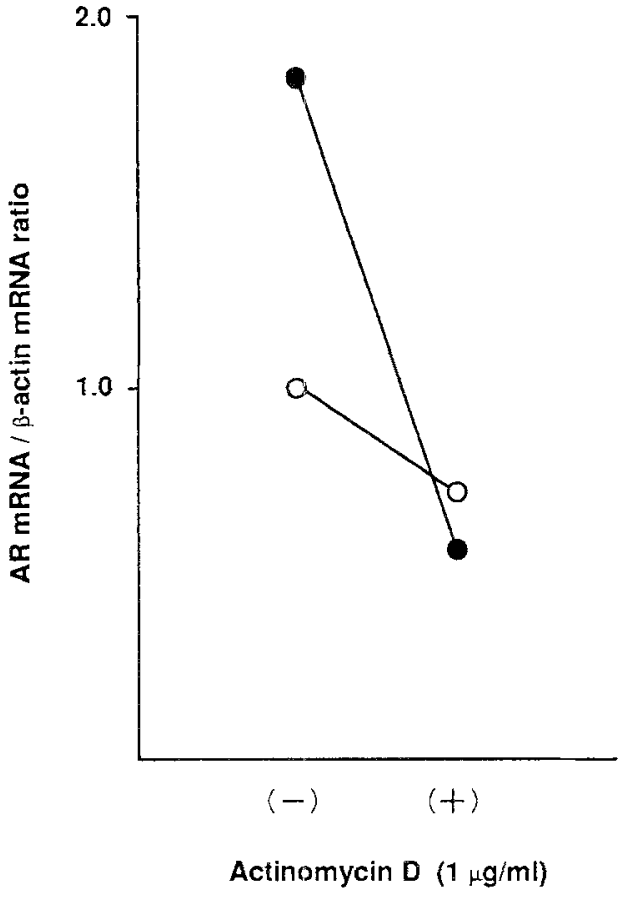

Fig. 4. The effect of actinomycin $D$ on aldose reductase (AR) mRNA expression. The ordinate indicates AR mRNA/ $\beta$-actin mRNA ratio in arbitrary units. The open and closed circles indicate $5.5 \mathrm{mmol} / \mathrm{l}$ and $18 \mathrm{mmol} / \mathrm{l}$ glucose, respectively. Actinomycin D was added $30 \mathrm{~min}$ before glucose exposure. The cells were incubated for $12 \mathrm{~h}$. The results are the means of the duplicates from representative experiments

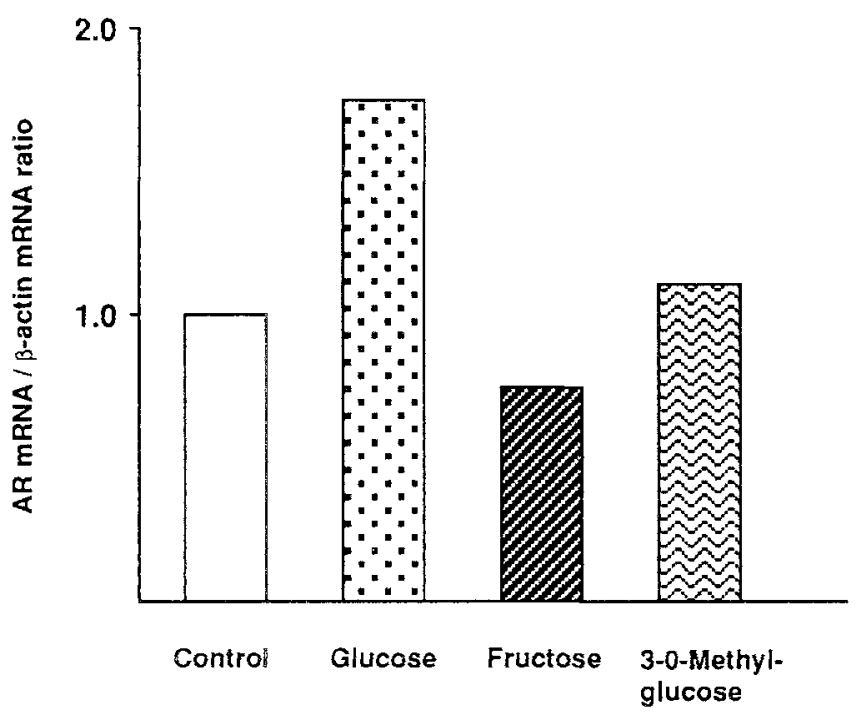

Fig. 5. The effect of other sugars on aldose reductase (AR) mRNA expression. Glucose, fructose and 3-O-methylglucose were added to the medium to study the effect of other sugars on AR mRNA expression. Each medium was prepared at $18 \mathrm{mOsm} / \mathrm{kg}$ except for control medium $(5.5 \mathrm{mOsm} / \mathrm{kg})$. The ordinate indicates $\mathrm{AR} \mathrm{mRNA} / \beta$ actin mRNA ratio in arbitrary units. The results are the means of duplicates from representative experiments

The above-listed conditions are considered to cause alterations in the function of endothelial cells, and are positive risk factors for the development of atherosclerosis.

Abnormal glucose metabolism and the subsequent accumulation of intracellular sorbitol caused by the activa- tion of $\mathrm{AR}$ in addition to the decrease in myo-inositol levels are reported to be one of the factors responsible for diabetic complications such as cataract, retinopathy, neuropathy and macroangiopathy [22-25].

In this study we have examined the modulation of AR mRNA expression and its activity by glucose in cultured CPAE cells. An important finding in this study is that AR mRNA expression and its activity increased when exposed to high glucose concentrations, commonly encountered in diabetic patients. This phenomenon is likely due to the induction of AR gene expression by glucose but not by other sugars or other osmolytes.

Our previous study demonstrated that diabetic patients with complications had an increased erythrocyte sorbitol/blood glucose ratio [26]. These findings may be explained by the induction of AR gene expression by glucose, although further studies are needed in human endothelial cells.

Interestingly, $\mathrm{AR}$ mRNA expression and its activity are inhibited at higher glucose concentrations $(55 \mathrm{mmol} / \mathrm{l})$. At present the precise mechanism is unknown, but two possibilities should be considered one being a feed-back inhibition in response to intracellular sorbitol accumulation. Bondy et al. [27] have reported that galactose feeding in the rat resulted in an increase in the renal medullary galactitol and profound decrease in renal medullary AR mRNA levels via a down regulation in response to AR end-product accumulation. Another possibility is a toxic effect under conditions of high ambient glucose. A toxic effect of sustained hyperglycaemia is suggested by the recent demonstration that in vivo exposure of endothelial cells to high glucose levels results in accelerated death, decreased replication and signs of DNA damage [28-30]. In fact, a toxic effect of glucose was observed in the cultures at the higher glucose concentrations (e.g. decrease in cell number and in adherence to dish) (data not shown).

Recent studies have reported that the products of the polyol pathway are stronger glycating agents than glucose $[31,32]$. A logical extension of this hypothesis is that induction of AR gene expression by glucose, although it may be transient, may result in cell dysfunction not only because of the increase in sorbitol level or the decrease in myoinositol level, but also because of the increase in glycation of intracellular proteins.

The present study is to our knowledge the first report demonstrating that glucose at a concentration observed in diabetic patients increases the levels of AR mRNA expression and AR activity in endothelium. Data from our study suggest that high blood glucose levels in endothelial cells increase AR mRNA expression with a subsequent increase in sorbitol and decrease in myo-inositol and possibly an increased glycation of proteins. This could result in damage to the endothelial cells and accelerate the development of vascular complications in diabetic patients. Investigations are now underway to determine whether AR mRNA expression is also induced by glucose in diabetic patients in vivo.

Acknowledgements. The authors wish to express their appreciation for the secretarial assistance of Ms. Y. Sato and Ms. M. Nakamura. 


\section{References}

1. Ross R (1986) The pathogenesis of atherosclerosis. N Engl J Med 314: $4.88-500$

2. Ross R, Glomset JA (1976) The pathogenesis of atherosclerosis. N Engl J Med 295: 369-377

3. Gabbay KH (1973) The sorbitol pathway and the complications of diabetes. N Engl J Med 288: 831-836

4. Kennedy A, Frank RN, Verma SD (1983) Aldose reductase activity in retinal and cerebral microvessels and cultured vascular cells. Invest Ophthalmol Vis Sci 24: $1250-1258$

5. Williamson JR, Chang K, Rowold E et al. (1985) Sorbinil prevents diabetes-induced increases in vascular permeability but does not alter collagen cross-linking. Diabetes 34: 703-705

6. Ghahary A, Luo J, Gong Y et al. (1989) Increased renal aldose reductase activity, immunoreactivity, and mRNA in streptozotocin-induced diabetic rats. Diabetes 38: 1067-1071

7. Bekhor I, Shi S, Unakar NJ (1990) Management of aldose reductase mRNA abundance in rat lens undergoing reversal of galactose induced cataracts. A model for gene response to changes in the environment. Mol Cell Biochem 95: 55-60

8. Deborah C, Kaneko M, Stark H et al. (1990) Increase in aldose reductase mRNA in dog lens epithelial cells under hypertonic conditions. Exp Eye Res 50: 743-749

9. Chelly J, Kaplan JC, Maire P, Gautron S, Kahn A (1988) Transcription of the dystrophin gene in human muscle and non muscle tissue. Nature 333: 858-860

10. Wang AM, Doyle MV, Mark DF (1989) Quantitation of mRNA by the polymerase chain reaction. Proc Natl Acad Sci USA 86: $9717-9721$

11. Maniatis T, Fritsch EF, Sambrook J, Nina I (1982) Extraction, purification, and analysis of messenger RNA from eukaryotic cells. In: Nancy F, Chris N, Michele F (eds) Molecular cloning: a laboratory manual. Cold Spring Harbor Lab., Cold Spring Harbor, pp 7.19-7.22

12. Buell GN, Wickens MP, Payvar F, Schimeke RT (1978) Synthesis of full length cDNAs from four partially purified oviduct mRNAs. J Biol Chem 253: 2471-2482

13. Petrash JM, Fanvello AD (1989) Isolation and characterization of cDNA clones encoding aldose reductase. Curr Eye Res 8: 1021-1027

14. Nudel U, Zakut R, Shani M, Neuman S, Levy Z, Yaffe D (1983) The nucleotide sequence of the rat cytoplasmic $\beta$-actin gene. Nucl Acids Res 11:1159-1171

15. Dufrane SP, Malaisse WJ, Sener A (1984) A micromethod for the assay of aldose reductase, its application to pancreatic islet. Biochem Med 32: 99-105

16. Gyllensten UB, Erlich HA (1988) Generation of single-stranded DNA by the polymerase chain reaction and its application to direct sequencing of the HLA-DQA locus. Proc Natl Acad Sci USA 85: 7652-7656

17. Brownlee M, Vlassara H, Cerami A (1984) Nonenzymatic glycosylation and the pathogenesis of diabetic complications. Ann Intern Med 101: 527-537
18. Sagel J, Colwell JA, Crook L, Laimins M (1975) Increased platelet aggregation in early diabetes mellitus. Ann Intern Med 82: 733-738

19. Mustard JF, Packham MA (1984) Platelets and diabetes mellitus. N Engl J Med 311: 665-667

20. Schonfeld G (1985) Diabetes, lipoproteins, and atherosclerosis. Metabolism 34: 45-50

21. Yamauchi T, Ohnaka K, Takayanagi R, Umeda F, Nawata $H$ (1990) Enhanced secretion of endothelin-1 by elevated glucose levels from cultured bovine aortic endothelial cells. FEBS Lett 267:16-18

22. Chylak LT, Kinoshita JH (1969) A biochemical evaluation of a cataract induced in a high glucose medium. Invest Ophthalmol Vis Sci 8: $401-402$

23. Greene DA, Lattimer SA, Sima AAF (1987) Sorbitol, phosphoinositides, and sodium-potassium-ATPase in the pathogenesis of diabetic complications. N Engl J Med 316: 599-606

24. Burg MB, Kador PF (1988) Sorbitol, osmoregulation, and the complications of diabetes. J Clin Invest $81: 635-640$

25. Morrison AD, Clements RS Jr, Winegrad AI (1972) Effects of elevated glucose concentrations on the metabolism of the aortic wall. J Clin Invest 51: 3114-3123

26. Aida K, Tawata M, Shindo H, Onaya T (1990) Clinical significance of erythrocyte sorbitol-blood glucose ratios in type 2 diabetes mellitus. Diabetes Care 13: 461-467

27. Bondy C, Cowley BD, Lightman SL Jr, Kador PF (1990) Feedback inhibition of aldose reductase gene expression in rat renal medulla. J Clin Invest 86:1103-1108

28. Lorenzi M, Cagliero E, Toledo S (1985) Glucose toxicity for human endothelial cells in culture: delayed replication, disturbed cell cycle, and accelerated death. Diabetes 34: 621-627

29. Lorenzi M, Montisano D, Toledo S, Barrieux A (1986) High glucose induces DNA damage in cultured human endothelial cells. J Clin Invest 77: 322-325

30. Capetandes A, Gerritsen ME (1986) The effects of elevated glucose concentration on cultured bovine retinal endothelial (BRE) cells. Fed Proc 45: 460 (Abstract)

31. McPherson JD, Shilton BH, Walton DJ (1988) Role of fructose in glycation and cross-linking of proteins. Biochemistry 27:19011907

32. Oimomi M, Sakai M, Ohara T et al. (1989) Acceleration of fructose mediated collagen glycation. J Int Med Res 17:249-253

Received: 11 February 1992

and in revised form: 21 April 1992

Dr. T. Onava

The Third Department of Internal Medicine

University of Yamanashi Medical School

Tamaho

Yamanashi 409-38

Japan 